UDC 376.06-056.264-053.4:811.161.2'34

DOI https://doi.org/10.32840/1992-5786.2020.73-1.29

L. V. Chemonina

Candidate of Pedagogical Sciences, Associate Professor, Associate Professor at the Department of Primary Education Berdyansk State Pedagogical University

A. S. Lesyk

Candidate of Pedagogical Sciences, Associate Professor, Associate Professor at the Department of Pedagogy Berdyansk State Pedagogical University

\title{
PECULIARITIES OF FORMATION OF THE COMMUNICATIVE COMPETENCE OF FIRST-GRADERS WITH AN IMPAIRMENT OF THE PHONATION SPEECH (ON THE EXAMPLE OF STUTTERING) IN THE PROCESS OF LEARNING THE SOUND SYSTEM OF THE UKRAINIAN LANGUAGE
}

The article is devoted to the topical problem of formation of first-graders' with disorders of phonation of speech (stuttering) communicative competence in the process of mastering the sound system of the Ukrainian language. The importance of students' mastering the ability to communicate in the state (and native in case of difference) language as one of the key competencies is noted. The role of work on the improvement of sound pronunciation, grammatical structure of oral speech, culture of speech and communication, which takes place during the children's acquaintance with the phonetic system of the Ukrainian language, as the main prerequisite for successful learning of primary school students in all subjects, is disclosed.

The analysis of leading scientists' scientific works, study of pedagogical experience and own observations of the educational process of modern primary school revealed a rapid increase in the number of first-graders with special needs, in particular speech disorders (stuttering). It is stated that one of the steps that ensures the full education of such children is inclusive education. It is emphasized that the main cause of mentioned above type of children's violation of phonation speech is a convulsive state. It is noted that teaching such a child to relax in the process of speech is one of the main tasks of a specialist in the field of primary education.

It is accented that it is possible to normalize the communicative activity of first-graders who suffer from stuttering with the help of special exercises. According to the authors of the article, exercises that provide an integrative approach to language learning are appropriate, that is allow to combine primary school students' activities which are specific to different educational fields in one lesson (e.g., language, literature and art). The study identified innovative teaching methods that will help a first-grader with special needs to relax the muscles of the speech apparatus ("singing" of the sounds), calm down and focus on educational material presented in the form of a game ("Sandliteracy", sculpting letters of the alphabet, etc.).

Key words: communicative competence, impairment of the phonation speech, stuttering, sound system of the Ukrainian language, primary school student.

Formulation of the problem. Nowadays attention is intensified to the acquisition of a person's key competencies, designed to ensure his / her orientation in modern society, to develop on the basis of mutual acceptance and mutual understanding a unified strategy of constructive interaction with other people, programming of the process of communication with them through overcoming the persistent stereotypes of behavior. In this context, young generation needs to master one of the key competencies the communicative one, which provides the ability and readiness of the individual to establish and maintain constructive interpersonal contacts, transmit and receive the necessary information in response.

An important period in the formation of communicative competence is the junior school age, when the child manifests the desire to call attention to his / her "l", to contrast oneself to others, to express his / her own position with respect to other people, to gain recognition from them, having taken an active part in various social relations, where the "l" of the child acts on an equal footing with the "l" of others. At this age there is the deployment of a certain position of the pupil in relation to people, which leads to the emergence of the possibility and need to implement the accumulated social experience in activities that are adequate to the overall level of personal development. That is, the active entry of first-graders into society occurs, along with appropriating its norms and rules of interpersonal communicative interaction [1].

The importance of communicative competence is also indicated in the valid documents, which ensure 
the existence of the system of Ukrainian education in general and the primary in particular. Thus, the main goal of language education is determined by the leading (communicative) function of the Ukrainian language and involves the cultivation of a nationally conscious, spiritually rich, creative individual who possesses the skills of communicatively expedient to use linguistic means in various spheres and kinds of speech activity [11]. There is no doubt that the formation of such a person is impossible without mastering the language as a means of communication, knowledge, self-affirmation in life, creative expression.

This is confirmed by the new State Standard of Elementary Education, in which the purpose of the language and literary educational sector is determined by the development of the pupil's personality, the formation of his / her communicative competence and general ideas about the language as a system and literature as a form of art [8].

The national doctrine of the development of education in Ukraine in the 21st century focuses modern educators on the personal orientation of education, which should ensure equal opportunities for children and young people in terms of obtaining quality education, ensuring the variability of this process in accordance with their abilities and individual capacities. However, as Z. Shevtsiv rightly points out, until recently organizational and methodological principles of a holistic pedagogical process of institutions of general secondary education have been focused on a pupil who develops in accordance to the norms defined for a certain age without taking into account the peculiarities of children psychophysical development $[5$, c. 6$]$.

Analysis of recent research and publications. The theoretical basis for the understanding of communicative competence is the following scientific provisions on the prominent role of communication for the progressive movement of the personality that is being formed and developed ( $\mathrm{V}$. Myasyshchev, G. Kostiuk); the existence of a communicative function of the psyche, along with cognitive and regulatory (B. Lomov); the concept of an active understanding of the communication process (O. Leontiev); the conceptual principle about the personality as an active subject, who is guided by "his / her own conscious aims and motives" in the activity and communication and the genetic and modeling approach to his / her study (S. Maksymenko); the principle on the ethical aspect of communication manifested in the attitude of personality to other people, the humane communicative strategy (K. Abul'khanova-Slavska, G. Ball, O. Bodal'yev).

The research of psychologists (Yu. Yemelyanov, V. Kan-Kalik, P. Klish, M. Kots', R. Osadchuk, Yu. Paskevs'ka, L. Petrovs'ka, S. Petrushyna, L. Rudyeva, L. Stolyarenko, S. Trubacheva, O. Tyuptya, A. Khom'yak, N. Shevchenko and others), teachers
(O. Verbyts'ky, M. Zazhyrko, N. Marets'ka, A. Mudryk, K. Ushyns'ky, O. Savchenko, V. Sukhomlyns'ky, V. Ternopil's'ka etc.) and linguodidacts (V. Bader, A. Bilyayev, L. Warzats'ka, M. Vashulenko, L. Mats'ko, O. Mel'nychayko, M. Pentylyuk, O. Khoroshkovs'ka, etc.) is devoted to the study of the problem of the communicative competence of the individual.

Attention to the notion of "communicative competence" as a scientific category falls in the 60's and 70 's of the twentieth century. However, today there is no unambiguous approach to its interpretation in psychological and pedagogical thought. This is due to the fact that "representatives of various branches of knowledge describe this concept from the standpoint of their own interests and emphasize in it what is most essential for this science" [2, c. 17-24].

Researchers who study communicative competence argue that the purpose of its development as a prerequisite for effective communication should be not so much the replacement of "natural" experience by other (more effective), but an organization or assistance in the self-organization of more effective ways of mastering the richness of communicative culture. After all, a person acquires the internal means of regulating communicative actions by learning a cultural heritage, observing the behavior of other people [4, c. 9-11].

Being engaged in issues of diagnostics and development of communication competence, Yu Zhukov, L. Petrovs'ka and P. Rastyannikov state that in order to communicate well, people should be communicatively competent. The mentioned above authors enroll a certain set of knowledge and skills in the structure of communicative competence, that provide an effective course of the communicative process. In other words, communicative competence is the ability to establish and maintain the necessary contacts with other people [4, c. 3]. The process of improving communicative competence cannot be separated from the general development of the individual. Therefore, mastering the means of regulation of communicative acts is an integral part of human culture, and their learning and enrichment takes place under the same laws as the mastering and multiplication of the cultural heritage as a whole [4, c. 9].

In detail the concept of "communicative competence" is analyzed in the studies of Yu. Yemelianov, who interprets this category as individual's ability, based on knowledge and feeling experience, to focus on situations of communication, fluency in verbal and nonverbal means of communication, emphasizing that such ability involves social and psychological training, or further opportunity to learn communication. The author also refers the ability of a person to organize the so-called interpersonal space in the process of initiative and active communication with people to the manifestation of communicative competence. The main factors that determine his / her development are 
human life experience, his / her general erudition, art, and special scientific methods [3].

As stated by V. Moskalenko, communicative competence can be defined as "the appropriate pragmatic use of social knowledge and communication skills" [7, c. 45]. According to M. Obozov, mentioned above definition can be interpreted in two aspects: the orientation of the individual in different situations of communication based on knowledge and sensual experience, and as ability to effectively interact with people through the understanding of oneself and others in terms of constant change in mental states, interpersonal relations and social situation. It is noted that communicative competence cannot be considered as a constant personal characteristic and be perceived as a locked up individual experience. It changes depending on the individual's level of assimilation of the culture of society, as well as his / her peculiarities of development and change of society itself [9, c. 88].

$M$. Pentiljuk understands the communicative competence as a perfect knowledge of communication skills in any environment under various circumstances. According to her conviction, ideally "it should be a person who not only knows the language, but freely and easily uses it in dialogical and monologue speech, loves his own language and respects other languages and their native speakers" [10, c. 70$]$.

The purpose of the article. The main purpose of this scientific work is to reveal the peculiarities of the formation of communicative competence of first-graders with impairments of phonation speech (on the example of stuttering) in the process of learning the sound system of the Ukrainian language.

Presenting main material. The conducted analysis of scientific sources shows that there are no unambiguous views on the essence of communicative competence in scientific sources. However, all researchers are unanimous in the fact that this phenomenon is complex in its essence and encompasses the knowledge, abilities and skills that ensure the transfer of information from one person to another through the establishment of effective contact, compliance with the relevant norms and rules of interpersonal interaction.

In this publication, we understand primary school pupils' communicative competence as an integrative personal formation that provides the establishment and maintenance of contacts with other people for the transmission of certain information, basing on knowledge of ethical norms of communication and valuable attitude towards them.

However, unfortunately, nowadays there is a rapid increase in the number of first-graders with special needs, in particular with speech disorders. Inclusive education is one of the steps that ensures the complete education of such children. We agree with Z. Shevtsiv that full involvement of mentioned above contingent of pupils in the educational process of a school provides the creation of a flexible educational system and represents a positive trend in its development [13].

Consequently, a modern specialist in the field of primary education should be aware of the medical pedagogical classification of speech disorders, according to which they are divided into two groups (depending on the violated type of speech) - oral speech impairments and written speech impairments. In this article we will consider peculiarities of formation of the communicative competence of first-graders with impairments of the phonation speech (on the example of stuttering) in the process of learning the sound system of the Ukrainian language.

Stuttering is an impairment of the tempo-rhythmic organization of speech, caused by the convulsive state of the muscles of the speech apparatus due to organic or functional nature [13, c. 135]. The structure of the speech defect in children with the mentioned above impairment of phonation speech (namely, stuttering) is highlighted in the works of L. Beliakova, V. Seliverstov, M. Sheremet and others [5, c. 341].

The development of speech, and hence the formation of communicative competence, takes place in the first grade at the initial stage of learning the language as a system. Thus, during acquaintance with the phonetic material, the current program of the subject "Ukrainian language" provides the improvement of sound pronunciation, grammatical structure of oral speech, work on the culture of speech and communication. We agree with M. Vashulenko, who claims that during this period the teacher is becoming familiar with the individual peculiarities of children's speech, the development of which will greatly influence on their success in studying of all subjects [6, c. 48].

A. Yastrebova rightly notes that the most often stuttering occurs when pronouncing the beginning of the word that "heads" the phrase. The reason for identifying this disadvantage can be the pupils' oral communication in unusual conditions [14]. It is possible to normalize communicative activity of first-graders suffering from stuttering, with the help of special exercises, including those developed by N. Chevelyova and A. Yastrebova.

Since the main reason for this type of impairment of phonation speech is the very convulsive spasm, it is advisable to teach the child to relax in the process of speech. In this case, in our opinion, exercises that provide an integrative approach to language learning, allowing to combine primary pupils' activities that are typical to various educational fields at one lesson (for example, language-literary and art) will be useful. Here are some examples.

\section{"Singing Alphabet"}

Make a "funny friend" which is the copy of the first letter of your name. What sound does this letter give? Sing it. 
To do the proposed tasks, a teacher offers first-graders to take pieces of the plasticine of their favorite color and roll them into a single mass, then make a certain letter (it can be both written and printed) and name the sound that it denotes. This way you can make the entire alphabet. Since one of the methods of stuttering's therapy is the encouragement to singing, in order to develop the correct speech breathing of the pupils with this speech impairment, the teacher should offer the specified contingent of children "to sing" the sound, which denotes the letter.

You can perform another composition in the same form: ask pupils to make certain syllables out of plastiline and then to make up words. "Singing" of formed syllables and words for junior pupils with impairments of phonation speech (stuttering) remains obligatory. We believe that this kind of activity allows to overcome the barrier of fear before studying a new letter and using its sound equivalent in pupil's own speech.

The possibilities of sand therapy are noteworthy of specialists' in the field of primary education who work with children impairments of the tempo-rhythmic organization of speech attention. We agree with $O$. Fediy, who observes that due to this relatively new method pupils' ability to express themselves and to percept of the world creatively is developed. Sand therapy helps to develop pupils' memory, attention and spatial imagination, to remove muscular tension [12]. We are convinced that it is expedient to offer the following differentiated task to first-graders who have impairments of phonation speech (stuttering).

\section{"Sand Literacy"}

Listen to the riddle.

This letter is in the words, and therefore it is welcomed by

a ballerina from the ballet and babies with bouquets.

A baby squirrel gives it a nut and a bee brings it a little honey.

What letter is it about? Write it on the sand. What sound does this letter denote?

Choose one task from the given below which you can do:

1. Make up syllables with the help of consonant sound $[b]$ and vowel sounds and write them down on the sand. Read these syllables by singing.

2. Write down the words with sound [b] at the beginning, in the middle and at the end of the word on the sand. Read them by singing.

3. Read the sentences by singing. Write down the syllables of words that have the sound [b] on the sand and name them.

Beavers and their babies

Are having fun at their burrow.

A beaver's burbling to a squirrel:

"My baby is afraid of bees!"

4. Read the given words by singing. Make up sentences with two of them and read them by singing. Draw a sound model of the word "birch" on the sand. Prove that you are not mistaken.

Bagel, goby, birch, zebra, bee, building.

Conclusions and suggestions. Thus, the analysis of scientific literature allows us to assert that the problem of formation of first-graders' communicative competence in the process of learning the sound system of the Ukrainian language is relevant. One of the main conditions for the formation of communicatively competent primary school pupils is an inclusive approach that ensures equal access to the education of all children, taking into account their educational needs, individual abilities and peculiarities of psychophysical development.

\section{References:}

1. Балл Г.О. Раціогуманістична орієнтація в методології людинознавства. Київ : Видавництво ПП «СДК», 2017. 204 с.

2. Гез Н.И. Формирование коммуникативной компетентности как объект зарубежных методических исследований. Иностранные языки в школе. 1985. № 2. С. 17-24.

3. Емельянов Ю.Н. Теория формирования и практика совершенствования коммуникативной компетентности. Санкт-Петербург, 1999. 403 с.

4. Жуков Ю.М., Петровская Л.А., Растянников П.В. Диагностика и развитие компетентности в общении: спецпрактикум по социальной психологии. Москва : Академия, 2007. 104 с.

5. Логопедія : підруч. / за ред. М.К. Шеремет. Київ : Видавничий дім «Слово», 2010. 376 с.

6. Методика навчання української мови в початковій школі : навч.-метод. посібн. для студ. ВН3 / за наук. ред. М.С. Вашуленка. Київ : Літера ЛТД, 2011. 364 с.

7. Москаленко В.В. Соціальна психологія : підручник. Вид. 2-ге, перероб. та доп. Київ : Центр учбової літератури, 2008. 688 с.

8. Нова українська школа: основи Стандарту освіти. Львів, 2016. 64 с.

9. Обозов Н.Н. Психология межличностных отношений. Киев : Лыбидь, 1990. 192 с.

10.Пентилюк М.I. Актуальні проблеми сучасної лінгводидактики : збірник статей / Марія Іванівна Пентилюк. К. : Ленвіт, 2012. 256 с.

11. Типові освітні програми для закл. загальної середньої освіти: початкова школа: іншомовна освіта + Державний стандарт початкової освіти. Київ : ТД «ОСВІТА-ЦЕНТР+», 2018. 80 c.

12.Федій О.А. Естетотерапія : навч. посіб. Київ : Центр учбової літератури, 2007. 256 с.

13.Шевців 3.М. Основи інклюзивної педагогіки : підручн. Київ : Центр учбової літератури, 2017. $248 \mathrm{c}$.

14.Ястребова А.В. Коррекция заикания в учащихся общеобразовательной школы : пособ. для учителей-логопедов. Москва : Просвещение, 1980. 104 c. 
Чемоніна Л. В., Лесик А. С. Особливості формування комунікативної компетентності першокласників із порушеннями фонаційного оформлення мовлення (на прикладі заїкання) у процесі засвоєння звукової системи української мови

Статтю присвячено актуальній проблемі формування комунікативної компетентності першокласників, які мають порушення фонаційного офоормлення мовлення (заїкання), у процесі засвоєння звукової системи української мови. Вказано на важливість оволодіння учнями вмінням спілкуватися державною (і рідною у разі відмінності) мовою як однією з ключових компетентностей. Розкрито роль роботи над удосконаленням звуковимови, граматичною будовою усного мовлення, культурою мовлення і спілкування, що має місце під час ознайомлення дітей із фронетичною системою української мови як основною передумовою для успішного навчання молодших школярів з усіх предметів.

Проведений аналіз наукових праць провідних учених, вивчення педагогічного досвіду і власні спостереження за освітнім процесом сучасної початкової школи дозволили констатувати стрімке зростання кількості учнів-першокласників з особливими потребами, зокрема з мовленнєвими порушеннями (заїканням). Підкреслено, що одним із кроків, який забезпечує повноцінну освіту таких дітей, $є$ інклюзивне навчання. Зроблено акцент на тому, що головною причиною названого вище виду порушення фонаційного мовлення дітей є саме судомний стан. Вказано, що навчити таку дитину розслаблятися у процесі мовлення - одне з основних завдань фрахівця в галузі початкової освіти.

Наголошено, що нормалізувати комунікативну діяльність першокласників, які страждають на заїкання, можливо за допомогою спеціальних вправ. Доцільними, на думку авторок статті, є вправи, які передбачають інтегративний підхід до навчання мови, тобто дозволяють на одному уроці поєднати види діяльності молодших школярів, що є характерними для різних освітніх галузей (наприклад, мовно-літературної та мистецької). У ході дослідження було визначено інноваційні методи навчання, які допоможуть першокласнику з особливими потребами розслабити м'язи мовленнєвого апарату («приспівування» звуків), заспокоїтися і зосередитися на навчальному матеріалі, поданому в ігровій формі («Пісочна грамота», ліплення букв алфравіту тощо).

Ключові слова: комунікативна компетентність, порушення фоннаційного оформлення мовлення, заїкання, звукова система української мови, молодший школяр. 